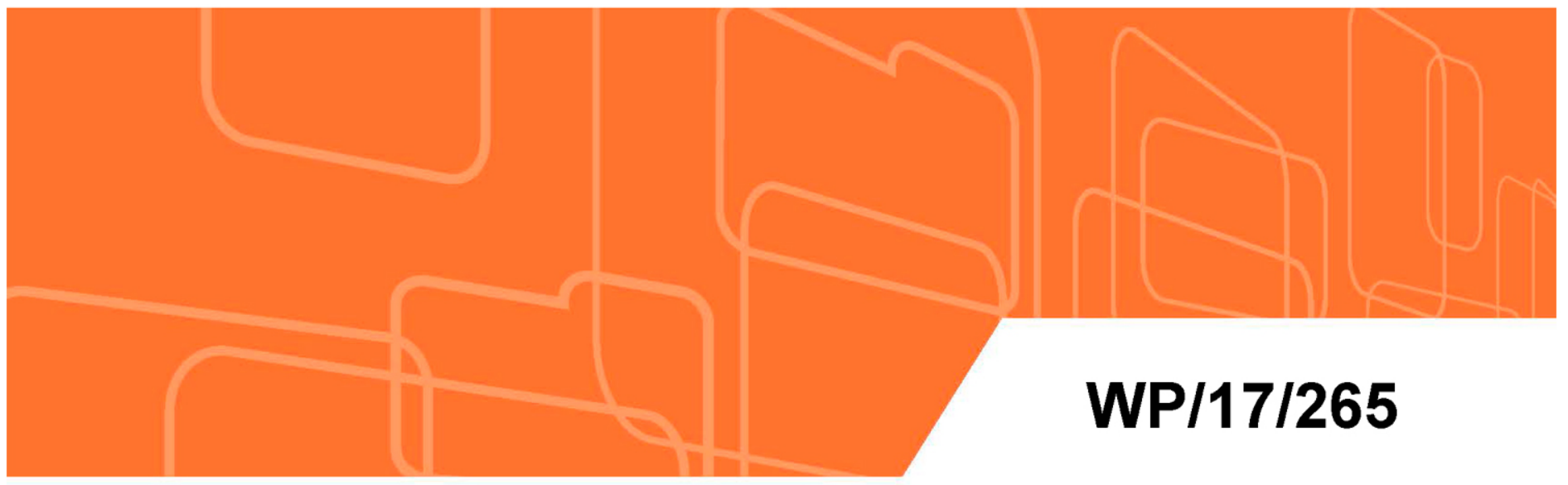

IMF Working Paper

\title{
Fiscal Federalism and Regional Performance
}

\author{
by Gabriel Di Bella, Oksana Dynnikova \\ and Francesco Grigoli
}

IMF Working Papers describe research in progress by the author(s) and are published to elicit comments and to encourage debate. The views expressed in IMF Working Papers are those of the author(s) and do not necessarily represent the views of the IMF, its Executive Board, or IMF management.

I N T E R N A T I O N A L M O N E T A R Y F U N D 


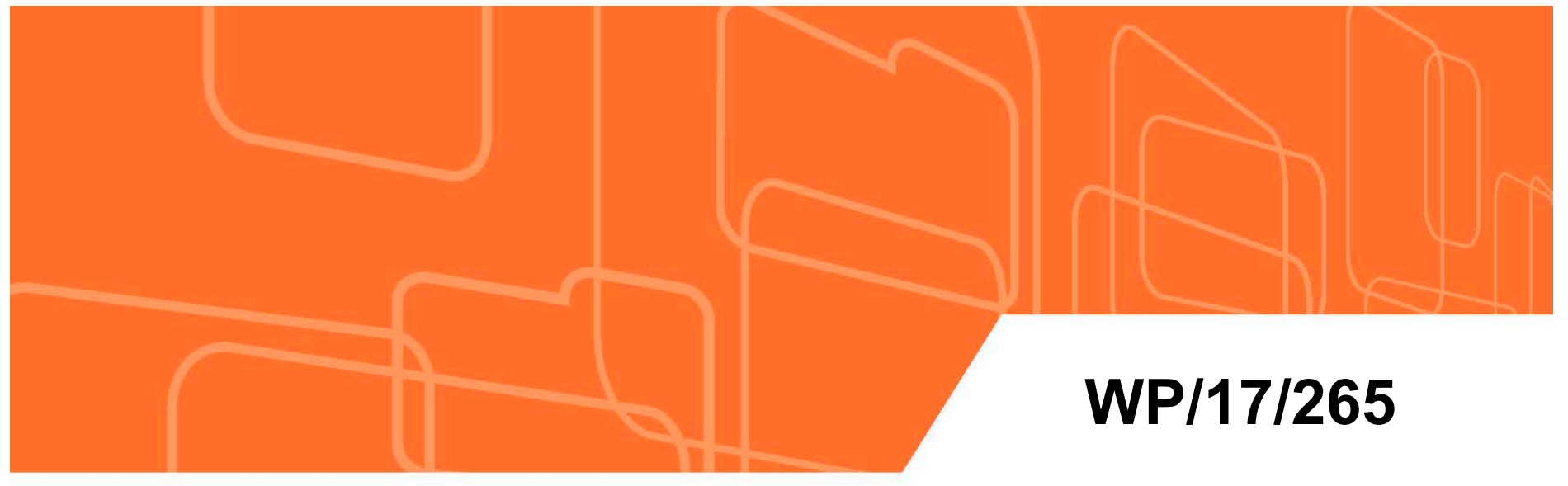

\title{
IMF Working Paper
}

\section{Fiscal Federalism and Regional Performance}

\author{
by Gabriel Di Bella, Oksana Dynnikova \\ and Francesco Grigoli
}

IMF Working Papers describe research in progress by the author(s) and are published to elicit comments and to encourage debate. The views expressed in IMF Working Papers are those of the author(s) and do not necessarily represent the views of the IMF, its Executive Board, or IMF management.
| N T E R N A T | O N A L
$M O N E$ T A R Y
F U N D 


\title{
Fiscal Federalism and Regional Performance*
}

\author{
Gabriel Di Bella ${ }^{\dagger} \quad$ Oksana Dynnikova ${ }^{\ddagger} \quad$ Francesco Grigoli $^{\S}$
}

\begin{abstract}
Sound regional policies are essential for balanced and sustained economic growth. The interaction of federal and regional policies with cross-regional structural differences affect human and physical capital formation, the business climate, private investment, market depth, and competition. This paper summarizes the main elements of Russia's fiscal federalism, describes the channels through which it operates, and assesses the effectiveness of regional transfers in reducing regional disparities. The results suggest that federal transfers to regions contributed to reducing disparities arising from heterogeneous regional tax bases and fiscal revenues. This allowed regions with initially lower per capita income to increase human and physical capital at higher rates. There is little evidence for transfers contributing to increased cross-regional growth synchronization. The results also suggest that federal transfers did not significantly improve regional fiscal sustainability, a conclusion that is supported by the lack of convergence in per capita real income across Russian regions in the last 15 years.
\end{abstract}

Keywords: Convergence, federalism, regional policies, Russia, transfers.

JEL Codes: H70, H71, H77.

* The views expressed in this Working Paper are those of the authors and do not necessarily represent those of the IMF or IMF policy. Working Papers describe research in progress by the authors and are published to elicit comments and to encourage debate. We thank to, without implicating, Suman Basu, Vladimir Kolychev, Alexander Morozov, Aleksei Mozhin, Ernesto Ramirez Rigo, and the participants of the IMF seminars held in May 2017 at the Central Bank of Russia and the Ministry of Finance of the Russian Federation for their comments and suggestions. We also wish to thank Nina Chebotareva and Tatiana Chernisheva for excellent research assistance.

$\dagger$ International Monetary Fund, European Department, gdibella@imf.org.

¥International Monetary Fund, European Department, odynnikova@imf.org.

§International Monetary Fund, Research Department, fgrigoli@imf.org.

\section{CInternational Monetary Fund. Not for Redistribution}




\section{Contents}

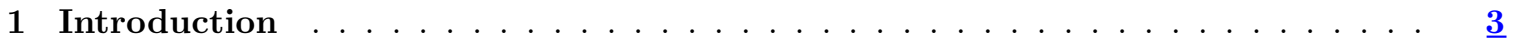

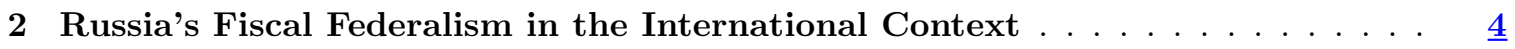

3 Federal Transfers to Regions: Achievements and Challenges . . . . . . . $\underline{\underline{6}}$

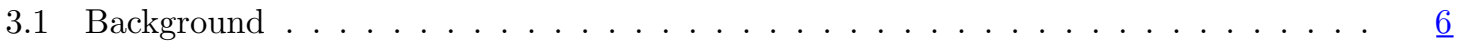

3.2 Federal Transfers and Public Goods' Supply Disparities . . . . . . . . . . . . . $\underline{8}$

3.3 Federal Transfers and Cross-Regional Growth Correlation . . . . . . . . . . . . $\underline{9}$

3.4 Federal Transfers and the Sustainability of Regional Budgets . . . . . . . . . . $\underline{11}$

4 Discussion and Some Policy Implications $\ldots \ldots \ldots \ldots \ldots \ldots \ldots$

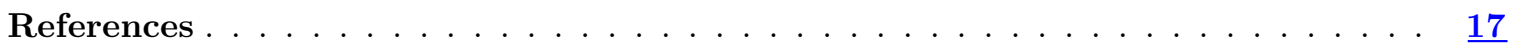

A Further Details about Fiscal Federalism in Russia . . . . . . . . . . . . . $\underline{\mathbf{1 9}}$

A.1 Limits Imposed by the Federal Government on Regional Budgets . . . . . . . . . . $\underline{19}$

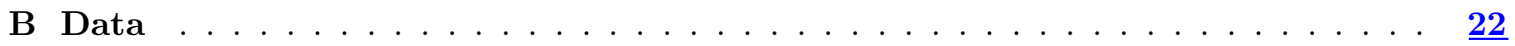

\section{List of Figures}

Page

Features of Russia's Fiscal Federalism . . . . . . . . . . . . . $\underline{5}$

Own Fiscal Revenues, Per Capita Income, and GRP Composition . . . . . . . . . $\underline{7}$

Federal Transfers and Per Capita Income . . . . . . . . . . . . . . $\underline{8}$

Federal Transfers and Accumulation of Factors of Production . . . . . . . . . . $\underline{9}$

Federal Transfers, Public Sector Expansion, and TFP Increases . . . . . . . . . . . $\underline{13}$

\section{List of Tables}

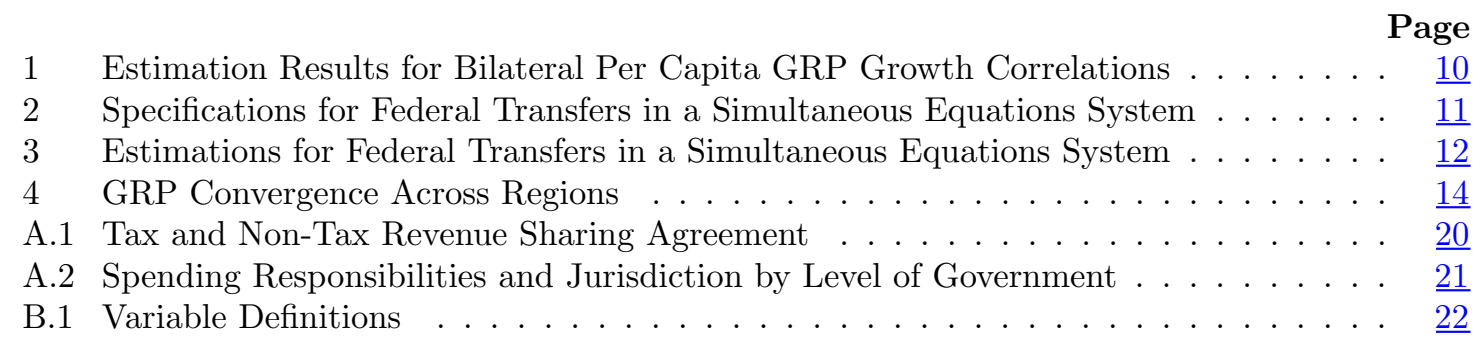




\section{Introduction}

Sound regional policies are essential for balanced and sustained economic growth. The interaction of federal and regional policies with cross-regional structural differences (e.g., natural resources, market size, distance to markets, historical events, among other) affect human and physical capital formation, the business climate, private investment, market depth, and competition. Policy pitfalls can be costly as they can result in persistent differences in regional per capita income, dependence on federal transfers, and excessive geographic concentration. Balanced regional development is a challenge that is particularly important in geographically large and heterogeneous countries (for a discussion of factors leading to uneven regional development, see Krugman, 1991).

Russia is a federal state in which regions have the legal responsibility - either exclusively or shared with the federal government-for education, health, and infrastructure spending. At the same time, Russia's fiscal constitution is more centralized than that in other federal countries. Its main building blocks are a relatively centralized tax authority and a complex system of federal transfers. Thus, the federal government plays a significant role in shaping regional outcomes. Federal transfers represented the economic lifeline of lower per capita income regions, which unsurprisingly have the weakest tax bases, for the last 15 years. Consolidated federal transfers, either from the federal budget or from federal extra budgetary funds (EBFs) to the regions (including territorial medical EBFs) amounted to 3.5 percent of GDP in 2016, or about 65 percent of federal oil and gas revenues. These transfers financed a large share of regional fiscal spending (e.g. almost 70 percent in the North Caucasus Federal Region, or about 40 percent in the Far Eastern Federal Region).

From a policy perspective, the large sub-federal share in general government spending - about 40 percent if territorial medical EBFs are considered - suggests that the fiscal stance is determined simultaneously by policies at the regional and federal level. ${ }^{1}$ Federal transfers may affect the degree of synchronization of regional growth, creating challenges (or improving) the effectiveness of stabilization policies, including monetary policy (Siluanov and Nazarov, 2009). Moreover, a large volume of transfers reduces the downward flexibility of federal spending, which can create challenges (including for a fiscal rule targeting a constant structural balance) as oil revenues gradually decrease. In this regard, federal transfers to regions add to other (earmarked) transfers, including those to the pension system and other EBFs, some of which will likely mount as population ages.

There is a large Russia-focused literature analyzing fiscal federalism and regional development. Some authors discuss the appropriate institutional design of fiscal federalism in Russia, including Lavrov et al. (2001), Khristenko (2002), Kadochnikov et al. (2002), Klimanov and Lavrov (2004), Shvetsov (2005), Yakobson (2006), Nazarov (2006), Grigoriev et al. (2008), Bukhval'd (2008), and Zubarevich (2014). Other authors focus on the challenges and outcomes of regional development in Russia, including Mau and Yanovskiy (2001), Granberg (2002), Pelyasov (2003), Alexandrova and Grishina (2005), Zubarevich (2009), and Yushkov (2016).

This paper attempts to empirically evaluate the relation between fiscal federalism and regional development in Russia. To that end, it compares Russia's fiscal federalism to that of other federal countries (Section 2), describes the channels through which fiscal federalism operates in Russia, assesses the effectiveness of regional transfers in reducing regional disparities in the provision of public services, analyzes the impact of transfers in synchronizing cross-regional growth, and evaluates the extent to which they have contributed to strengthen the regions' fiscal sustainability (Sec-

\footnotetext{
${ }^{1}$ The share of regional spending to general government spending in Russia is lower than in Canada, the United States, and Mexico, but similar to that in a number of other OECD countries including Belgium, Germany, and Spain (OECD, 2016).
} 
tion 3). The paper concludes with a discussion of the results, some policy implications and issues for further analysis (Section 4). The results suggest that federal transfers to regions contributed to reducing disparities arising from heterogeneous regional tax bases and fiscal revenues. This allowed regions with initially lower per capita income to increase human and physical capital at higher rates. There is little evidence for transfers contributing to increased cross-regional growth synchronization. The results also suggest that federal transfers did not significantly improve regional fiscal sustainability, a conclusion that is supported by the lack of convergence in per capita real income across Russian regions in the last two decades. ${ }^{2}$

\section{Russia's Fiscal Federalism in the International Context}

Fiscal federalism arrangements in Russia are involved. There are three levels of governmentfederal, regional, and local - with the local level further subdivided into a hierarchy of municipalities, which in total count more than 22,000. The Budget Code states that each of the three levels is autonomous and should be financially self-sustained. However, a complex system of intragovernment transfers (mostly flowing from the federal government) ensures that spending of most regions, territorial EBFs, and federal EBFs remain broadly financed. A large network (counting more than 65,000) of budgetary, extra-budgetary, unitary enterprises, and joint stock companies (most of which operating at the regional level) adds to complexity.

Russia's legal framework is consistent with an integrated fiscal constitution. A main conclusion in Blöchliger and Kantorowicz (2016) is that through clustering of fiscal constitutions characterized by similar features it is possible to classify countries in either those having integrated fiscal constitutions or to those having decentralized ones. Decentralized fiscal constitutions (e.g., Canada and the United States) are consistent with sub-national governments (SNG) having more autonomy and responsibility, lower co-determination of policies, and relatively weaker numerical budget rules and frameworks. Integrated, or centralized, fiscal frameworks are characterized by lower autonomy and responsibility of SNGs and, at least de jure, stronger fiscal rules and frameworks.

In what follows, we rely on the data from Blöchliger and Kantorowicz (ibid.) to look into Russia's fiscal federalism and compare it with that of other federal countries. Their analysis together with a reading of Russia's legal framework, allows to understand the relative weight of the federal and regional governments in shaping cross-regional socio-economic outcomes. ${ }^{3}$ In particular, the framework for intergovernmental fiscal relations is assessed and quantified along five categories: the autonomy of SNGs, the responsibility for their own fiscal policies, their power to shape federal policy, the strength of budget frameworks, and the overall system's stability. Each of these categories (as well as sub-categories) is evaluated by looking at several sub-indicators whose performance is assessed with an index ranging from zero (low) to one (high). As this analysis is for some of the indicators mainly de jure, the description below notes, when appropriate, any differences with de facto realities in Russia. ${ }^{4}$

Russia's SNGs have weaker tax autonomy than spending autonomy relative to other federal countries. The autonomy of SNGs (top left panel of Figure 1) is analyzed looking at both tax and spending autonomy. Tax autonomy is assessed by looking at each tax category and evaluating whether the federal government, SNGs, or both, can affect tax rates, as well as with respect to

\footnotetext{
${ }^{2}$ Appendix A provides further details about the distribution of revenue authority, sharing arrangements, intragovernmental transfers, spending jurisdictions among levels of government, and the limits imposed by the federal government on the regions' budgets.

${ }^{3}$ See Appendix A for further details.

${ }^{4}$ For a more comprehensive discussion see Blöchliger and Kantorowicz (2016)
} 
the clarity with which the law assigns power between different levels of governments. Likewise, spending autonomy is evaluated at each policy area, and assessing the respective responsibilities of SNGs and the federal government. In other sub-categories (namely, borrowing and budgetary autonomy), Russia ranks below the average of advanced economies and similar to the average of other emerging markets.

Figure 1: Features of Russia's Fiscal Federalism
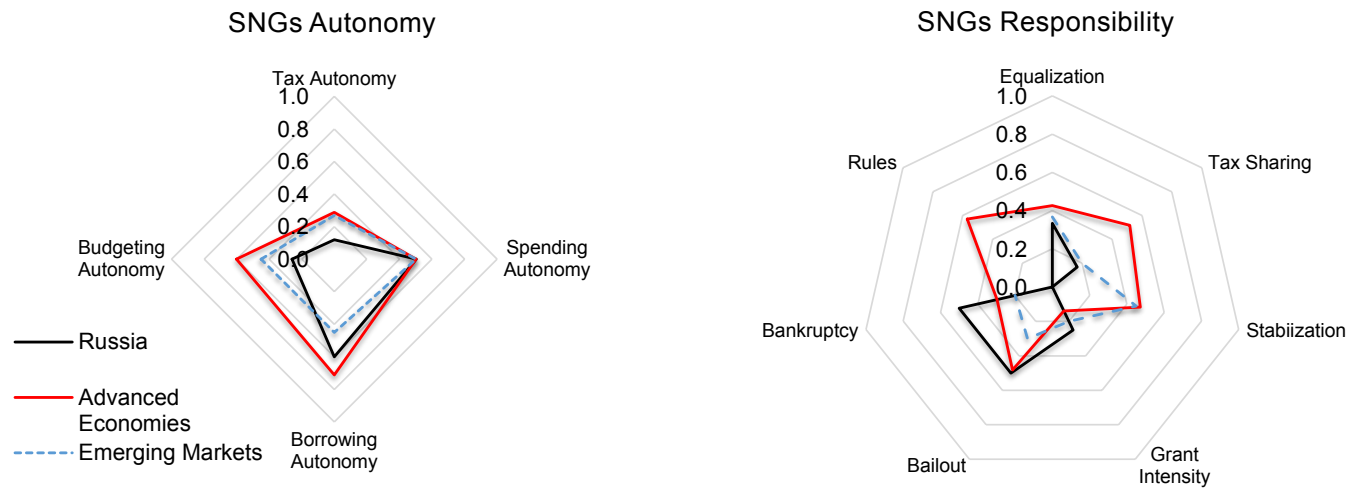

Co-determination of Federal Policies

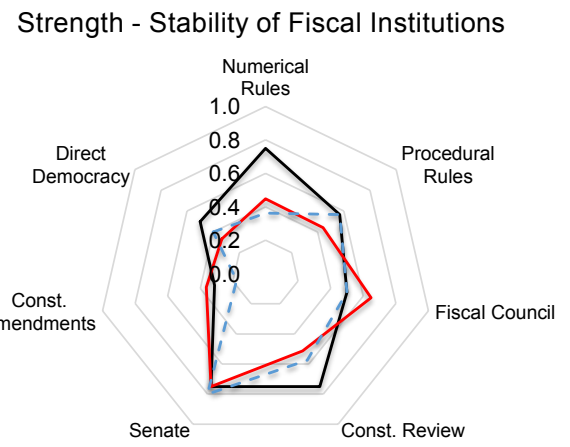

Source: Authors' calculations and OECD (2016).

A look at Russia's SNGs responsibility (top right panel of Figure 1) suggests that the federal government plays a relatively more important role in regional fiscal policy in Russia than in both advanced and other emerging market economies. In terms of the sub-categories, fiscal equalization policy in Russia is more the responsibility of the federal government than that of SNGs, and stabilization policy is fully in the hands of the federal government. The intensity of federal grants (which may be underestimated in Blöchliger and Kantorowicz (2016) as they measure it in terms of aggregate GDP rather than in terms of the gross regional product, GRP, of recipient regions), also suggests an important role for the federal government in shaping regional outcomes. A de jure evaluation of the possibility of regional bailouts or bankruptcies situates Russia in a better position than the average of advanced and other emerging market economies, although de facto the federal government as recently as in 2015-16 resorted to transfers to ease the burden of public debt in some regions. ${ }^{5}$

\footnotetext{
${ }^{5}$ Tabakh and Andreeva (2015) analyze the debt strategies of Russian regions, and Blagoveschensky (2014) the solvency of Russian regions.
}

\section{CInternational Monetary Fund. Not for Redistribution}


Finally, Russia's legal framework obtains higher marks than the average of advanced and other emerging market economies in co-determination of federal policies (bottom left panel of Figure 1) and the stability of its fiscal constitution (bottom right panel of Figure 1). However, de jure versus de facto considerations play a role in this assessment. For instance, although Russia's budget code included some form of a fiscal rule since 2008, its parameters changed, and its implementation was suspended a few times. Regarding the stability of the legal framework, Russia suffered numerous modifications of the operational framework establishing the relation between the federal and regional governments, including on tax sharing and transfers.

\section{Federal Transfers to Regions: Achievements and Challenges}

This section begins with some background information about Russia's tax sharing arrangements, the types of federal transfers, and the fiscal situation of Russian regions. It then presents an empirical analysis of the effectiveness of federal transfers in equalizing the provision of public services, in increasing the correlation of cross-regional growth rates, and in delivering sustainable regional budgets.

The econometric analysis uses panel data for 79 regions covering a large variety of regional socioeconomic variables, including economic activity, labor, fiscal, financial, and structural indicators. The data spans the period 2000-16, although some variables are available for shorter time periods (i.e., regional fiscal data for 2005-16, GRP for 2000-15, and GRP composition for 2004-15). A cross-sectional dataset is then constructed in which each observation represents some bilateral interaction between two regions (e.g., difference in growth rates, level differences, or correlation) for a given variable.

\subsection{Background}

Regional revenues include own revenues and federal transfers. The share of federal transfers in regional revenue varies widely across regions, ranging from about 10 percent to 90 percent. Federal taxes (most importantly personal and corporate income tax) are the largest source of regional revenue, representing on average about 70 percent of own revenues. Tax sharing, or primary distribution, allocates tax revenues among different levels of government. Ideally, it should result in vertical fairness, i.e., in a balanced distribution of revenues among federal, regional, and local governments. It is performed directly in the regions where taxes are collected on a tax-by-tax basis at predetermined rates. Sharing arrangements and rates are governed by the Budget Code, and in the case of the corporate income tax by the Tax Code. Regional excises' shares are determined by the Budget Code with horizontal (i.e., cross-regional) re-distribution. Rates tend to be adjusted frequently. ${ }^{6}$

The primary distribution of taxes results in a large cross-regional dispersion of fiscal revenues (or horizontal disparity, i.e., differences in the revenues within a level of government), however some relationships hold steady. Specifically, regions with lower per capita real GRP have lower per capita real own revenues (top left panel of Figure 2). In regions in which the public sector's share in GRP is high, per capita real fiscal revenues tend to be lower (top right panel of Figure 2). Also, and in line with the literature (Leuthold, 1991; Sen Gupta, 2007), per capita fiscal revenues are positively associated with the share of mining in GRP and negatively associated with the share of

\footnotetext{
${ }^{6}$ See Appendix A for more details.
} 
agriculture (bottom panels of Figure 2). In other words, regional tax bases are positively associated with per-capita GRP, with the share of mining in GRP, and negatively associated with the share of agriculture, and that of the public sector.

Figure 2: Own Fiscal Revenues, Per Capita Income, and GRP Composition
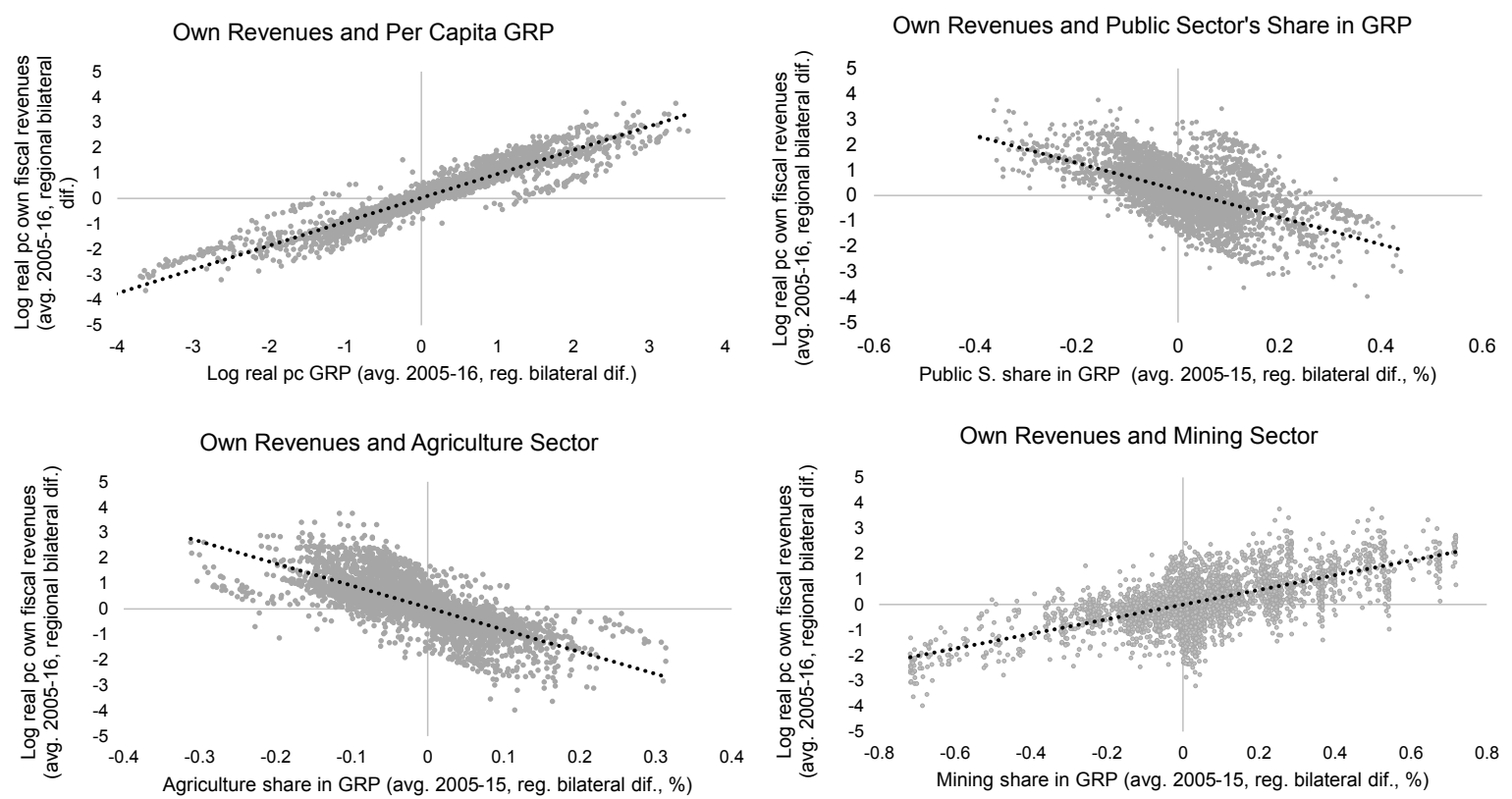

Source: Authors' calculations.

Notes: The black dashed lines represent the linear regression lines.

Intra-governmental federal transfers aim at reducing horizontal fiscal inequality. These include (i) non-earmarked and non-matching transfers (of which equalization grants are the most important); (ii) subsidies (earmarked matching transfers to finance spending priorities); (iii) subventions (earmarked non-matching transfers to finance devolved spending responsibilities); and (iv) other transfers. In addition, there are transfers from the Federal Medical Insurance Fund (a federal EBF), to Territorial Medical Insurance Funds (regional EBFs), which represented 1.7 percent of GDP in 2016. ${ }^{7}$ Equalization grants constitute about 50 percent of federal government transfers. ${ }^{8}$ In per capita real terms equalization grants flow mostly to regions with both lower per capita income and lower own fiscal revenues. In contrast, subsidies and subventions in per capita real terms are allocated to regions with higher per capita income (Figure 3$).^{9}$

Regions and municipalities are largely responsible for social policies as well as for some regional infrastructure. In 2016, regional spending represented 95 percent of general government expenditure for housing and utilities, 80 percent for education and cultural activities, and around 85 percent for health including spending by territorial extra-budgetary medical funds.

\footnotetext{
${ }^{7}$ About 40 percent of these transfers are financed by contributions to the Federal Medical Fund from regional budgets on behalf of the non-working population.

${ }^{8}$ See Appendix A for more details.

${ }^{9}$ Federal budget spending for national economy includes transfers and subsidies to support economic activity, which can benefit firms either privately or state-owned. Although this category of spending has a regional dimension, this dimension is not legally codified.
} 
Figure 3: Federal Transfers and Per Capita Income
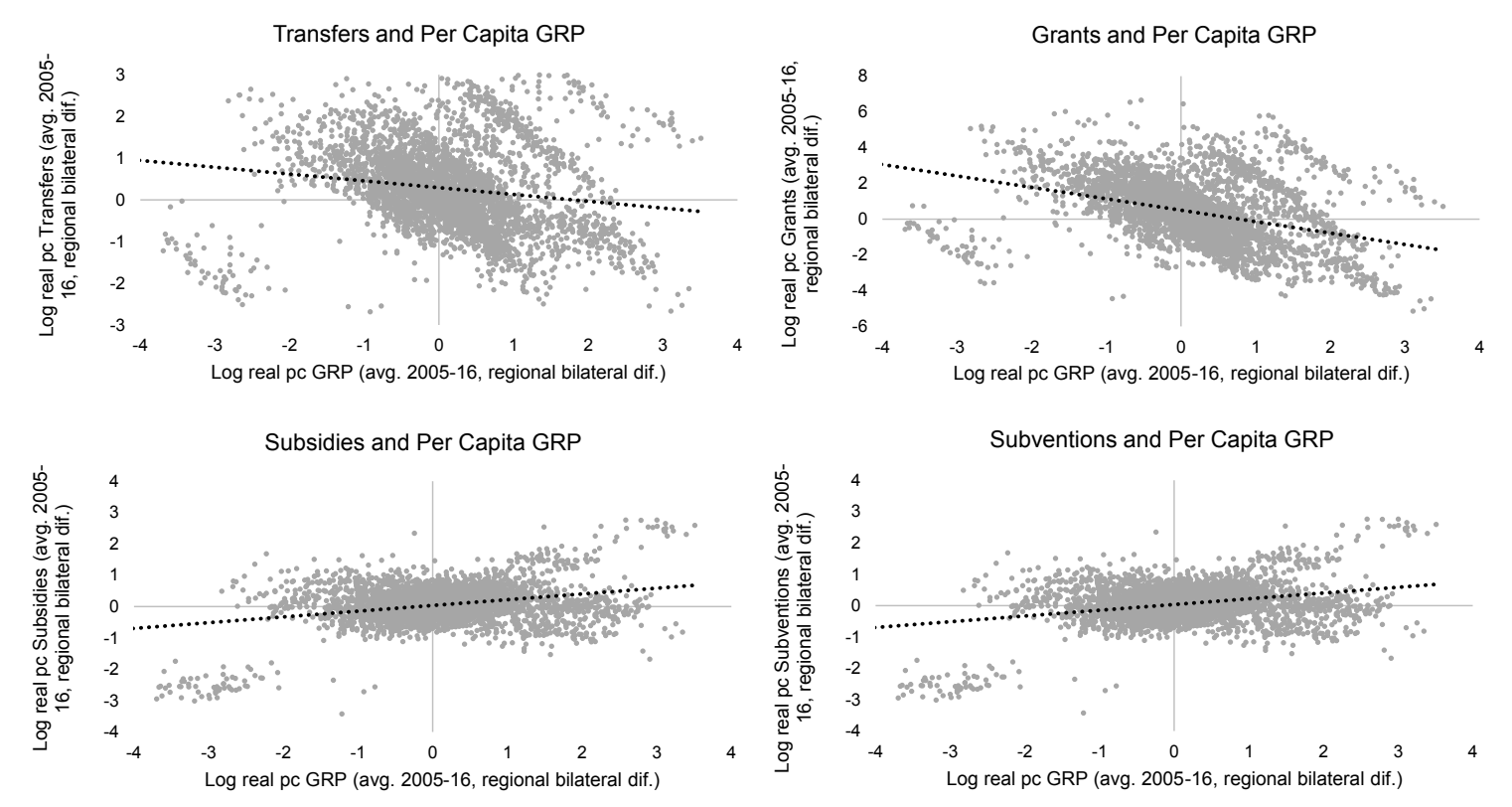

Source: Authors' calculations

Notes: The black dashed lines represent the linear regression lines.

\subsection{Federal Transfers and Public Goods' Supply Disparities}

In principle, a large portion of federal transfers to regions aim at reducing disparities arising from heterogeneous regional tax bases and unequal own revenues. A look at the data shows that indeed the distribution of cross-regional per capita real expenditure is situated to the right of the distribution of per capita real own revenues. This implies that lower income regions can afford higher public real per capita spending than warranted by their own regional revenues.

Moreover, higher average federal transfers to regions in 2005-16 (in per capita real terms) are positively associated with larger increases in per capita real annual spending in health and education, helping lower income regions to partially close the gap with richer regions in per capita social spending (top panels of Figure 4). Larger federal transfers are also positively associated with stronger human capital accumulation. Educational attainment together with employment data allows constructing regional measures of human capital using a methodology similar to that in Hall and Jones (1999), which assumes diminishing returns for additional years of education. ${ }^{10}$ The resulting human capital measures show that it grows at higher rates in regions that receive higher average transfers (in GRP terms) (bottom left panel of Figure 4). This result, however, is partially driven by cross-regional differences in labor supply.

\footnotetext{
${ }^{10}$ Human capital indices are constructed assuming decreasing returns of additional years of education. In other words, the increase in human capital of finishing primary school (with respect to having no schooling at all) is higher than the increase in finishing secondary education (with respect to having finalized basic education only). We assign decreasing returns to the five different categories of education that are reported by the national statistics agency (Rosstat), namely basic, secondary, secondary technical, university, and post-graduate. These calculations are available upon request
} 
In addition, investment-to-GRP ratios and physical capital accumulation are generally higher in regions receiving larger federal transfers. The construction of regional capital stocks by means of the perpetual inventory method shows that physical capital accumulation in regions with initially lower per capita income and that receive larger transfers is faster than in other regions (bottom right panel of 4). The very high investment ratios (in some cases as high as 50 percent of GRP) highlight, however, that initial capital stocks in lower income per capita regions were likely very low when compared with richer regions. ${ }^{11}$

Figure 4: Federal Transfers and Accumulation of Factors of Production
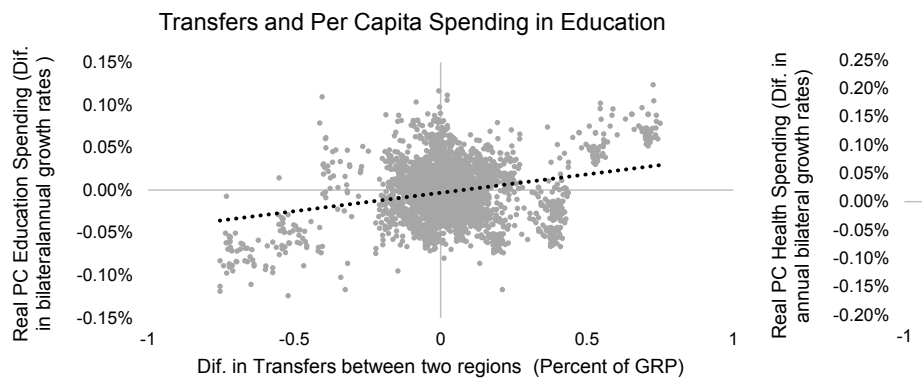

Transfers and Per Capita Spending in Health
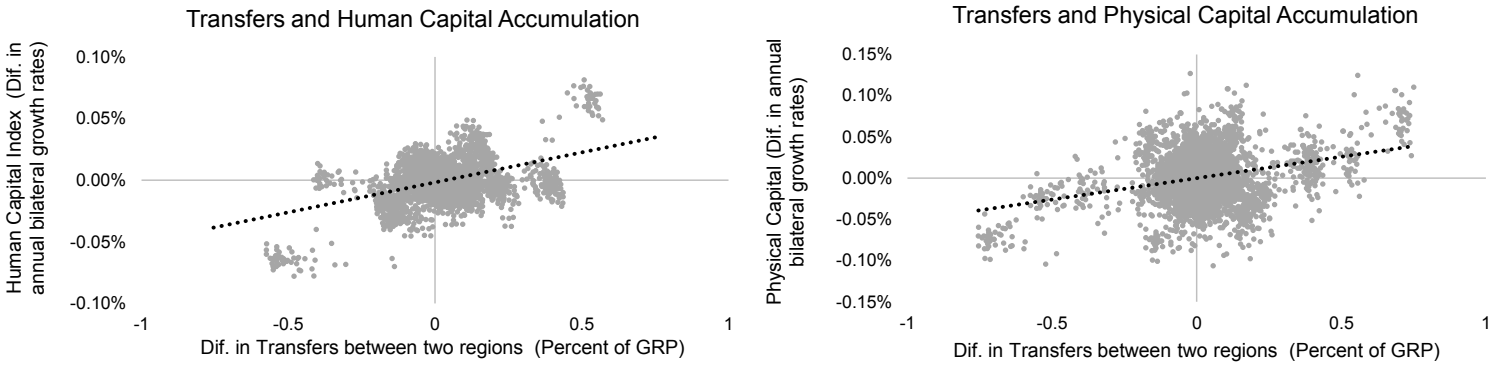

Source: Authors' calculations.

Notes: The black dashed lines represent the linear regression lines.

\subsection{Federal Transfers and Cross-Regional Growth Correlation}

Given the central role that the federal government plays in economic stabilization, a federal policy that smooths out aggregate economic cycles and strengthens cross-regional growth correlations should have positive spillovers for the effectiveness of monetary policy. ${ }^{12}$ To test whether federal transfers contribute to increase the synchronization of real GRP growth rates, we estimate the following equation:

$$
\rho_{i, j}\left(y_{i}, y_{j}\right)=\alpha+\beta \theta_{i, j}\left(f t_{i}, f t_{j}\right)+\gamma X_{i, j}+\epsilon_{i, j}
$$

\footnotetext{
${ }^{11}$ The link between regional investment and transfers is straightforward. The budget finances a relatively large share of regional investment in regions receiving larger transfers, in particular lower-income regions. A similar pattern is observed when looking at gross investment by ownership (private, public, and mixed): public sector investment is larger in regions receiving larger transfers.

${ }^{12}$ This is a similar argument to that made in the optimal currency area literature (Mundell, 1961).
} 
where $\rho\left(y_{i}, y_{j}\right)$ is the correlation coefficient between the per capita real GRP growth rate, denoted by $y$, of region $i$ and region $j ; \theta\left(f t_{i}, f t_{j}\right)$ is the correlation coefficient between the growth rate of per capita real federal transfers (on aggregate and by type of transfer), denoted by $f t$, of region $i$ and region $j ; X_{i, j}$ is a set of control variables (including proxies for distance, GRP structure, footprint of the state, and international trade) calculated as the pairwise difference between two regions of the variable being considered $;^{13} \alpha$ is a constant; $\beta$ and $\gamma$ are the coefficients of the correlation coefficient and the control variables, respectively; and $\epsilon_{i, j}$ is the error term. ${ }^{14,15}$

Table 1 presents the results for eleven alternative specifications. We find evidence that aggregate transfers do not have a strong or robust association with bilateral cross-regional growth correlation. Among transfer types, the same applies for per capita real grant growth rates (whose purpose is to reduce cross-regional spending disparities) and per capita real subsidies growth rates. The coefficient for per capita real subventions growth rates are somewhat significant in some specifications, though this should be taken with caution due to potential endogeneity. ${ }^{16,17}$. The positive association between per capita real GRP growth correlations and that of per capita real subventions growth rates can be either desirable or not, depending on whether federal fiscal policy amplifies or lessens the severity of overall economic cycles. The evidence for Russia in the last two decades suggests that federal fiscal policy has been somewhat pro-cyclical (Erbil, 2011).

Table 1: Estimation Results for Bilateral Per Capita GRP Growth Correlations

\begin{tabular}{|c|c|c|c|c|c|c|c|c|c|c|c|c|}
\hline Variable & & 1 & 2 & 3 & 4 & 5 & 6 & 7 & 8 & 9 & 10 & 11 \\
\hline Constant & $\alpha_{1}$ & $0.514 * * *$ & $0.530 * * *$ & $0.524 * * *$ & $0.561 * * *$ & $0.566 * * *$ & $0.562 * * *$ & $0.559 * * *$ & $0.566 * * *$ & 0.374 * & 0.149 & 0.149 \\
\hline Per capita real federal transfers growth corr. & $\beta_{2}$ & 0.065 & 0.051 & 0.047 & 0.034 & 0.021 & 0.023 & 0.025 & & & & \\
\hline Per capita real grant growth corr. & $\beta_{3}$ & & & & & & & & 0.013 & 0.005 & 0.002 & \\
\hline Per capita real subsidies growth corr. & $\beta_{4}$ & & & & & & & & & 0.264 & 0.209 & 0.209 \\
\hline Per capita real subventions growth corr. & $\beta_{5}$ & & & & & & & & & & 0.356 * & 0.356 * \\
\hline Initial per capita real GRP & $\gamma_{6}$ & & -0.071 & -0.069 & -0.142 *** & -0.124 ** & -0.104 & -0.101 & -0.102 & -0.096 & -0.085 & -0.085 \\
\hline Common border & $\gamma_{7}$ & & & 0.126 & 0.086 & 0.088 & 0.096 & 0.097 & 0.098 & 0.088 & 0.070 & 0.070 \\
\hline Share of public sector in GRP & $\gamma_{8}$ & & & & $-1.218^{* * *}$ & -0.784 & -0.814 & -0.853 & -0.854 & -0.807 & -0.813 & -0.812 \\
\hline Footprint of state & $\gamma_{9}$ & & & & & -0.090 & -0.097 & -0.095 & -0.096 & -0.096 & -0.083 & -0.083 \\
\hline Urbanization rates & $\gamma_{10}$ & & & & & & -0.155 & -0.132 & -0.132 & -0.148 & -0.189 & -0.189 \\
\hline Foreign trade & $\gamma_{11}$ & & & & & & & -0.043 & -0.043 & -0.041 & -0.054 & -0.054 \\
\hline$R^{2}$ & & 0.003 & 0.030 & 0.038 & 0.136 & 0.160 & 0.164 & 0.166 & 0.166 & 0.177 & 0.209 & 0.209 \\
\hline Adj. $R^{2}$ & & 0.003 & 0.029 & 0.037 & 0.135 & 0.159 & 0.163 & 0.164 & 0.164 & 0.175 & 0.207 & 0.207 \\
\hline Observations & & 3,023 & 3,023 & 3,023 & 3,023 & 3,023 & 3,023 & 3,023 & 3,023 & 3,023 & 3,023 & 3,023 \\
\hline
\end{tabular}

Notes: Robust standard errors, ${ }^{*} p<0.1,{ }^{* *} p<0.05,{ }^{* * *} p<0.01$.

\footnotetext{
${ }^{13}$ The footprint of the state is defined as the number of per capita regional budget and non-budgetary entities, including state unitary enterprises and joint-stock companies

${ }^{14}$ See Appendix B for the definition of the variables used in the specifications.

${ }^{15}$ Since bilateral observations for region pair $(i, j)$ are not independent from the bilateral observations for the region pair, say, $(i, k)$, the actual degrees of freedom are $n-k-1$, where $n$ is the number of the regions rather than the number of observations, and $k$ is the number of the independent variables. Standard errors are corrected accordingly.

${ }^{16}$ Imbs (2004) estimates a cross-regional growth correlation equation within a system to allow for endogeneity of some of the right hand side variables. However, to our knowledge, there is no inter-regional trade data available for Russia, preventing this sort of analysis. Also, as noted by Imbs (ibid.) differentiating between cyclical and structural effects can be revealing, but we refrain from doing this due to the reduced time series length.

${ }^{17}$ Yushkov (2016) analyzes the role of subventions in Russia's fiscal federalism.
} 


\subsection{Federal Transfers and the Sustainability of Regional Budgets}

Federal transfers affect regional fiscal sustainability through different channels. To assess the effect of federal transfers on the regions' fiscal sustainability, we estimate a system of equations allowing for feedback effects among endogenous variables:

$$
Y_{i, t}^{m}=\alpha+\beta Y_{i, t}^{-m}+\gamma Z_{i, t}+\epsilon_{i, j}
$$

where $Y_{i, t}$ is a matrix of endogenous variables including the long-term change in the revenue-toexpenditure ratio (our proxy for fiscal sustainability), the cumulated per capita real GRP growth, the long-term percentage change in the share of public sector in GRP, and the long-term average of federal transfers in percent of GRP; ${ }^{18} Z_{i, t}$ is a matrix of exogenous variables including the level of initial per capita real GRP, the share of mining in GRP, population size, population density, common border (as a proxy for geographic distance), and the footprint of state; ${ }^{19} m$ is the equation index; $\alpha$ is a vector of constant terms; $\beta$ is the matrix of coefficients of the endogenous variables; $\gamma$ is the matrix of coefficients of the exogenous variables; and $\epsilon_{i, j}$ is a vector of the error terms. Table 2 shows the identifying restrictions to estimate the system.

Table 2: Specifications for Federal Transfers in a Simultaneous Equations System

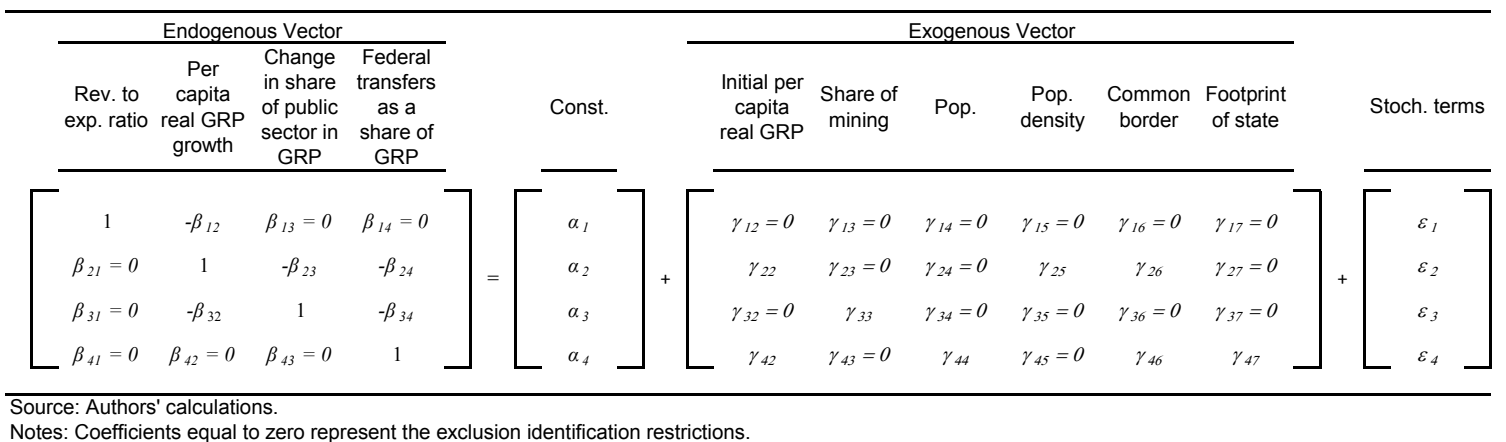

Notes: Coefficients equal to zero represent the exclusion identification restrictions.

The identification of the model assumes that federal transfers affect fiscal sustainability through their impact on regional tax bases, which should expand faster in regions in which cumulated GRP growth is higher. Differences in GRP growth rates are assumed to be endogenously determined by differences in economic structure (i.e., whether the private or the public sector is expanding more rapidly), by differences in federal transfers (regions receiving larger transfers could accumulate factors of production faster), and to depend on a number of predetermined and exogenous variables (the level of initial real per capita GRP, population density, and geographic distance). Regional economic structure is assumed to depend endogenously on federal transfers and per capita real GRP growth, while federal transfers are assumed to be explained by exogenous and predetermined variables (including bilateral differences in the initial level of real per capita GRP).

\footnotetext{
${ }^{18}$ The public sector is defined as the sum of the share of public administration; military security; social insurance; education; health care and social services; and, other communal, social, and personal services. Note that the private sector is defined as sum of the rest of economic activities, despite the fact that it comprises the operations of SOEs in these activities.

${ }^{19}$ The common border dummy variable is time invariant.
} 
The results in Table 3 suggest that federal transfers did not significantly contribute to improve regional fiscal sustainability. This is visible by analyzing the channels through which federal transfers led to changes in per capita real GRP growth rates. On the one hand, comparing pairs of regions, those that received larger federal transfers grew faster (direct effect), possibly due to a more rapid accumulation of factors of production, as described above; on the other hand, the share of the public sector expanded comparatively more (10-year cumulative increase) in regions receiving larger federal transfers, which subtracted from per capita real GRP growth dynamism (indirect effect), with the negative (indirect) impact more than offsetting the positive (direct) one. Given the positive association between own revenue-to-expenditure ratio and per capita real GRP growth, which takes place through the positive effect of per capita real GRP growth on tax bases, it can be inferred that federal transfers did not result in an improvement of regional fiscal sustainability. For instance, our estimates suggest that a one-standard deviation difference in the level of federal transfers (about 17 percent of regional GRP) is associated with a negative cumulative bilateral difference in per capita real GRP growth (over 2005-15) of around 1.2 percentage points, an increase in the bilateral share of public sector in GRP of around 1.5 percentage points, and with no improvement in the (own) revenue-to-expenditure ratio. These results are particularly relevant for around one third of Russia's regions (28 out of 79 in the sample), which receive federal transfers that are higher than the average by between one and three standard deviations.

Table 3: Estimations for Federal Transfers in a Simultaneous Equations System

\begin{tabular}{|c|c|c|c|c|c|c|c|}
\hline Equation & Variable & Coefficient & SUR & $2 S L S$ & $3 S L S$ & FIML & GMM \\
\hline & & \multicolumn{6}{|c|}{ Endogenous } \\
\hline 1 & Per capita real GRP growth & $\beta_{12}$ & $0.280 * * *$ & $0.743^{* * *}$ & $0.717^{* * *}$ & $1.099 * \star \star$ & $0.754^{* \star *}$ \\
\hline 2 & Chg. in share of public sector in GRP & $\beta_{23}$ & $-0.320 * * *$ & -0.504 & -0.431 & -0.236 & -0.373 \\
\hline 2 & Federal transfers as a share of GRP & $\beta_{24}$ & 0.011 & 0.051 & 0.034 & 0.023 & 0.025 \\
\hline 3 & Per capita real GRP growth & $\beta_{32}$ & $-1.360^{* * *}$ & -0.628 & -0.573 & -0.502 & -0.683 \\
\hline \multirow[t]{2}{*}{4} & Federal transfers as a share of GRP & $\beta_{34}$ & $0.083^{* *}$ & $0.104 * \star$ & 0.090 * & 0.087 & 0.099 * \\
\hline & & \multicolumn{6}{|c|}{ Exogenous } \\
\hline 1 & Constant & $\alpha_{1}$ & 0.002 & 0.004 * & 0.004 * & $0.005^{*}$ & 0.004 * \\
\hline 2 & Constant & $\alpha_{2}$ & 0.001 & 0.001 & 0.001 & -0.001 & 0.000 \\
\hline 2 & Initial per capita real GRP & $\gamma_{22}$ & $-0.010^{* \star *}$ & -0.007 & $-0.011^{\star * *}$ & $-0.009 * *$ & $-0.011 * * *$ \\
\hline 2 & Population density & $\gamma_{25}$ & 0.001 & 0.002 & 0.001 & 0.000 & 0.001 \\
\hline 2 & Common border & $\gamma_{26}$ & 0.000 & 0.003 & -0.002 & -0.002 & -0.002 \\
\hline 3 & Constant & $\alpha_{3}$ & 0.002 & 0.004 & 0.004 & 0.004 & 0.003 \\
\hline 3 & Share of mining & $\gamma_{33}$ & $-0.053^{* *}$ & -0.046 & -0.041 & -0.042 & $-0.042 *$ \\
\hline 4 & Constant & $\alpha_{4}$ & 0.022 * & 0.024 * & 0.023 * & 0.024 * & 0.021 \\
\hline 4 & Initial per capita real GRP & $\gamma_{42}$ & $-0.058^{* \star *}$ & $-0.068^{* * *}$ & $-0.062 * * *$ & $-0.067^{\star \star \star}$ & $-0.049 * * *$ \\
\hline 4 & Population & $\gamma_{44}$ & $-0.046^{* * *}$ & $-0.048^{* * *}$ & $-0.043^{* * *}$ & $-0.043^{* * *}$ & -0.039 *** \\
\hline 4 & Common border & $\gamma_{46}$ & -0.025 & -0.032 & -0.024 & -0.025 & -0.024 \\
\hline 4 & Footprint of state & $\gamma_{47}$ & 0.033 & 0.031 & 0.034 & 0.034 & 0.037 * \\
\hline
\end{tabular}

Source: Authors' calculations.

Notes: Robust standard errors, ${ }^{\star} p<0.1,{ }^{\star \star} p<0.05$, ${ }^{\star \star \star} p<0.01$.

Accordingly, regions receiving larger federal transfers did not close (even partially) the gap between their expenditures and own revenues. This is the case as economic growth based on the expansion of government services did not result in an improvement in own revenue-to-GRP ratios, which (in levels) are positively correlated with the size of the private sector (Figure 2). Thus, the financial dependence of many of these regions on federal transfers remained broadly unchanged. This dependence is summarized by the fact that for many of them their own revenues continue to be barely sufficient to finance health and education spending.

An alternative way to interpret the results is that, at least during the period analyzed, federal transfers were insufficient to jump-start self-sustaining, private-sector led growth in regions receiving relatively more transfers. Federal transfers should, in the short term, increase the size 
of the public sector as transfers push social and infrastructure spending upwards; however, they should not necessarily result, a priori, in a long-term increase in the share of the public sector in GRP. Indeed, it can be expected that the increased supply of public goods (e.g., in the form of higher human and physical capital) would result in positive spillovers for the private sector, but this is not observed. A possibility is that a by-product of federal transfers is to support a larger state footprint in regions; there is some evidence for this, as federal transfers flowed to regions not only with lower initial per capita real GRP, but also with a relatively larger footprint of the state (equation 4 in Table 3).

We indirectly test the robustness of these results by means of complementary analysis. First, we find that for pairs of regions, total factor productivity (TFP) expanded at lower annual rates in regions receiving relatively higher levels of federal transfers. This means that the distance in productivity levels between low- and high-income regions increased in the last 15 years (Figure 5). We come to these results by recovering neutral TFP levels for the period 2000-15 using a production function approach based on an identical Cobb-Douglas production function for all regions. We construct regional capital stocks using the perpetual inventory method and regional investment, and we calculate effective human capital (i.e., corrected for labor utilization) using educational attainment of the employed working-age population.

Figure 5: Federal Transfers, Public Sector Expansion, and TFP Increases
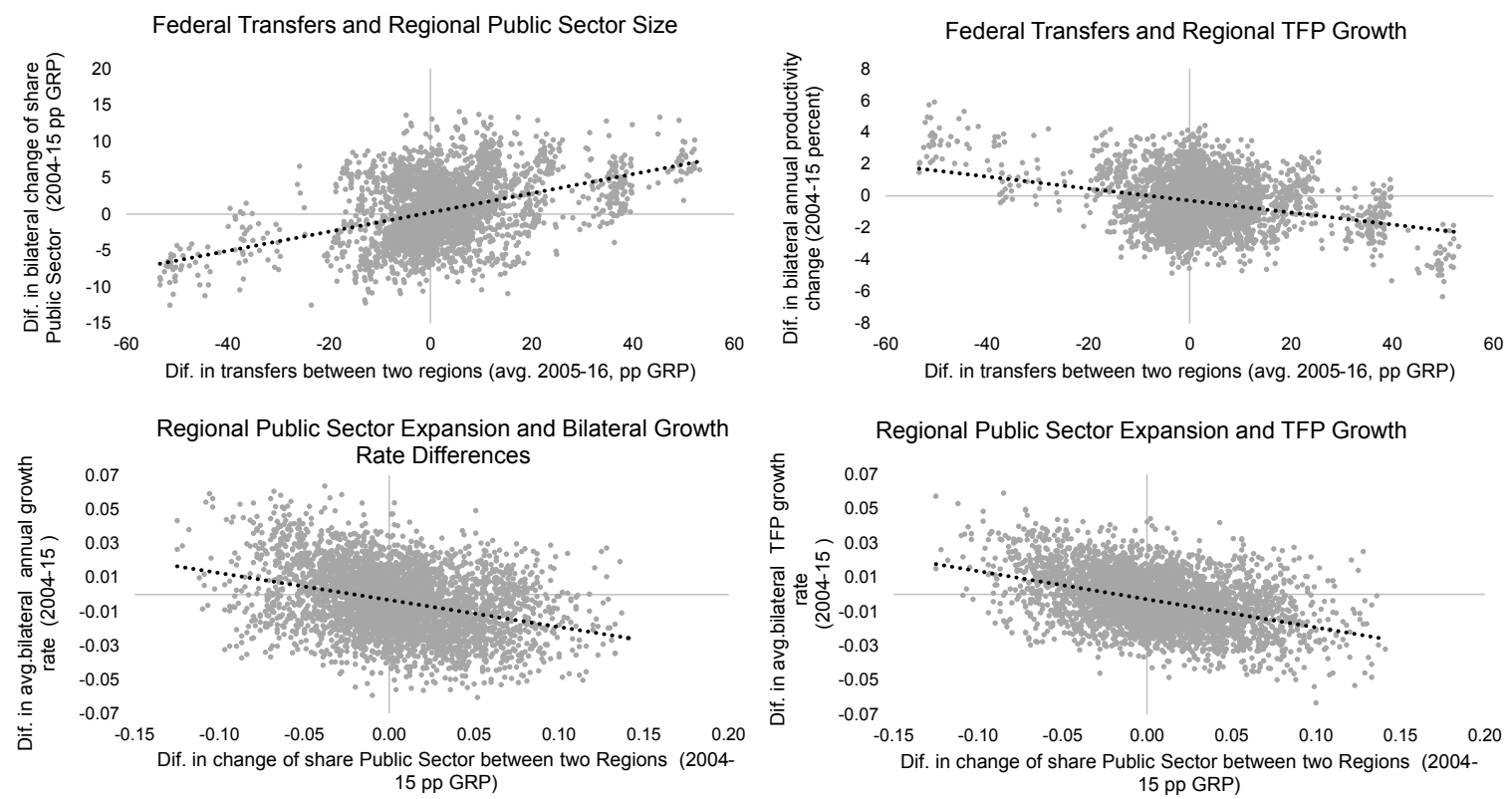

Source: Authors' calculations.

Notes: The black dashed lines represent the linear regression lines.

Second, we find no evidence of convergence in real per capita income across Russian federal regions in the period 1998-2015 (Table 4). Following Pedroni and Yao (2006), we test for convergence across federal regions in the sample and across regions in different geographical areas with the panel unit root tests of Im et al. (2003) and Maddala and Wu (1999). Apart from the FarEastern Federal Region that shows some convergence at the 10 percent significance level, there is no convergence across the identified clubs. 
Table 4: GRP Convergence Across Regions

\begin{tabular}{|c|c|c|c|c|}
\hline \multirow[b]{2}{*}{$\begin{array}{l}\text { Full sample } \\
\qquad\left(y_{i t-} \bar{y}_{t}\right) \forall i\end{array}$} & & Countries & $\begin{array}{l}\text { Im, Pesaran, } \\
\text { and Shin (2003) }\end{array}$ & $\begin{array}{c}\text { Maddala and } \\
\text { Wu (1999) }\end{array}$ \\
\hline & & 84 & 0.105 & 195.050 \\
\hline \multicolumn{5}{|l|}{ Regions } \\
\hline$\left(y_{i t-} \bar{y}_{t}\right) \forall i \in$ & Central Federal Region & 19 & 4.075 & 15.456 \\
\hline$\left(y_{i t-} \bar{y}_{t}\right) \forall i \in$ & Northwestern Federal Region & 11 & -0.049 & 21.417 \\
\hline$\left(y_{i t-} \bar{y}_{t}\right) \forall i \in$ & Southern Federal Region & 6 & 0.145 & 9.938 \\
\hline$\left(y_{i t-} \bar{y}_{t}\right) \forall i \in$ & North-Caucasus Federal Region & 6 & -1.274 & 18.264 \\
\hline$\left(y_{i t-} \bar{y}_{t}\right) \forall i \in$ & Volga' s Federal Region & 15 & 0.032 & 29.083 \\
\hline$\left(y_{i t-} \bar{y}_{t}\right) \forall i \in$ & Ural's Federal Region & 5 & -0.536 & 16.871 \\
\hline$\left(y_{i t-} \bar{y}_{t}\right) \forall i \in$ & Siberian Federal Region & 12 & 0.813 & 23.932 \\
\hline$\left(y_{i t-} \bar{y}_{t}\right) \forall i \in$ & Far-Eastern Federal Region & 10 & $-2.863^{*}$ & $43.252^{*}$ \\
\hline
\end{tabular}

Third, population concentration in higher-income geographical areas increased in the last 15 years. For instance, the population of the city of Moscow increased by more than 30 percent since the year 2000, and by 10 percent in Saint Petersburg, against the backdrop of a broadly constant total population. This implies that other less densely populated (and generally lower-income) regions experienced population decreases of 15-20 percent. Although concentration has some advantages for recipient regions and cities (e.g., increases economies of scale, supports firm localization, improves job matching, among other), it has symmetrical drawbacks for regions losing population, and results in an increasing per capita cost for federal transfers. More broadly, it results in geographically unbalanced development, a critical issue for a continental-sized country like Russia. Federal transfers - and fiscal federalism in Russia more generally - appear not to have taken into consideration both the advantages or disadvantages related with increased concentration and the associated regional challenges that may arise as a consequence. ${ }^{20}$

\section{Discussion and Some Policy Implications}

Russia's fiscal federalism assigns a strong role to the federal government. The system evolved from a somewhat disorderly decentralization in the 1990s into a more centralized system in the last 15 years. Regions play an essential role in human and physical capital formation, but cross-country comparisons of fiscal constitutions suggest that they have less autonomy and exercise less control of their own fiscal policy than in other federal countries. The system is quite complex and the diversity of federal subjects along socio-economic dimensions is wide. Increased coordination between the federal and regional governments to tackle complexity and to address cross-regional infrastructure and human capital bottlenecks could result in a more integrated national market with positive spillovers for inter-regional and international trade and investment. ${ }^{21}$ Regional convergence can result in a growth dividend and in more balanced geographical development.

\footnotetext{
${ }^{20}$ The literature includes analysis of internal migration trends in Russia (Riazantsev, 2005), of urban trends (Kolomak, 2014) and of the importance of regional capitals (Leksin, 2006).

${ }^{21}$ Ongoing work to measure regional business climate with a view of strengthening institutions may promote higher private investment for a given level of federal transfers.
} 
Given relatively rigid tax sharing arrangements, federal transfers constitute one of the main levers through which federal policy operates at the regional level. Federal transfers proved effective in supporting factor accumulation in lower per capita income regions. However, there is little evidence that transfers contributed to increased cross-regional growth synchronization, which is not necessarily a negative outcome given that fiscal policy has been somewhat pro-cyclical. Federal transfers were ineffective in supporting self-sustaining per capita real GRP growth and productivity increases. Transfers expanded government services but did not result in a long-term increase in the share of the private sector in GRP. Accordingly, large cross-sectional differences in own fiscal revenues (in per capita and GRP terms) persist, as well as the associated dependence on federal transfers. Importantly, federal transfers flow more heavily to regions where the footprint of the state is larger, which may suggest a self-sustaining pattern. ${ }^{22}$

Enhanced strategic direction could help increasing federal transfers' growth effectiveness. Openended transfers may have had the unintended effect of weakening regional incentives to enlarge their tax bases, supporting a pattern of dependence. Thought should be given to include in the grant allocation formulas a stronger measure of sustainability together with the current objective of equalization. Establishing realistic transition periods to achieve sustainability is essential.

Appropriate federal macroeconomic and tax policies can contribute to the development of regional tax bases, supporting regional sustainability, and the accountability of regional authorities. An option in this regard could be to expand the use of personal property taxes (OECD, 2016). Personal property taxes currently represent only 0.4 percent of the consolidated own revenues of regions. In 2016, 28 regions started a transition to market value-based instead of accounting value-based taxation of property. For instance, the city of Moscow is projecting a five-fold increase in property tax collections by 2020 (with tax collection increasing by 55 percent in 2016). Larger regional tax bases should also balance somewhat the strong de jure role of the federal government.

Given that higher income regions have more space to strengthen their own tax bases (e.g., through taxation of property as indicated above, which is more abundant and of higher value in richer regions), there may be scope to increase the use of horizontal transfers in the margin. The large cross-regional dispersion of per capita own revenues may have contributed to economic and population concentration, which creates negative spillovers for regions with population outflows. ${ }^{23}$ Consideration should be given to modify incentives with the aim of limiting concentration. The use of horizontal transfers, in the margin, may contribute to that effect and support the use of improved levels of human and physical capital in lower per capita income regions. ${ }^{24}$

The sustained implementation of a credible fiscal rule should contribute to avoid stop-go cycles caused by terms of trade shocks, promote a more stable and more aligned-with-fundamentals real exchange rate with positive spillovers for lower per capita income regions, where agriculture (a tradable sector) represents a larger share of GRP. This should have beneficial effects for the expansion of regional tax bases. A fiscal rule would also contribute to smooth national and regional economic cycles, simplifying the implementation of stabilization policies (including monetary policy). The role of different types of federal transfers in the synchronization of regional economic cycles deserves further analysis. Rebalancing domestic taxes with a view to taxing labor less heavily should support decreases in informality, which is likely more prevalent in low per capita income

\footnotetext{
${ }^{22}$ The complete elimination of regional dispersion is unlikely. Going forward, equalization grants will likely keep their leading role. Sudden decreases or reallocations could create disruptions especially in the most financially dependent regions.

${ }^{23}$ Yushkov et al. (2017) analyze the trajectories for Russia's "donor" regions.

${ }^{24}$ In this regard, there may be room to gradually improve the primary distribution of corporate income tax (CIT). The ongoing redistribution (by the federal government) of one percentage point of CIT to finance equalization grants is an example of the use of horizontal transfers in the margin.
} 
regions as attested by weaker tax bases.

Finally, there may be room to simplify and increase the transparency of transfers. Streamlining the number of transfers (especially subsidies), in particular for agriculture development, housing and utilities, and education; allocating subsidies one-to-one to government programs (or subprograms), instead of to a multiplicity of them; transforming and further consolidating "other transfers" into subsidies; and regulating budget loans, which are increasingly used because of their concessional interest rates, should all result in a simpler, more transparent, and easy-to-administer system. 


\section{References}

Alexandrova, Anastasiya and Elena Grishina (2005). "Non Uniform Development of Municipalities". In: Voprosy Ekonomiki 8, pp. 97-105.

Blagoveschensky, Yuri (2014). "Financial Solvency of Russian Regions 2005-2011: Experience of Classification Analysis". In: New Economic Association Journal 2(23), pp. 61-88.

Blöchliger, Hansjörg and Jaroslaw Kantorowicz (2016). "Fiscal Constitutions: An Empirical Assessment". In: Chapter 2, Fiscal Federalism 2016: Making Decentralization Work.

Bukhval'd, Evgenij (2008). "Russian Federalism and a Critical Stage of Development". In: Voprosy Ekonomiki 9, pp. 70-83.

Erbil, Nese (2011). "Is Fiscal Policy Procyclical in Developing Oil-Producing Countries?" In: International Monetary Fund Working Paper 11/171.

Granberg, Alexander (2002). "The Strategy of Territorial Social and Economic Development of Russia: From Idea to Implementation". In: Voprosy Ekonomiki 8.

Grigoriev, Leonid, Natalia Zubarevich, and Yulia Urozhaeva (2008). "Scylla and Charibdis of Regional Policy". In: Voprosy Ekonomiki 2, pp. 83-98.

Hall, Robert E and Charles I Jones (1999). "Why Do Some Countries Produce so Much More Output per Worker than Others?" In: The Quarterly Journal of Economics 114.1, pp. 83-116.

Im, Kyung So, M Hashem Pesaran, and Yongcheol Shin (2003). "Testing for Unit Roots in Heterogeneous Panels". In: Journal of Econometrics 115.1, pp. 53-74.

Imbs, Jean (2004). "Trade, Finance, Specialization, and Synchronization". In: The Review of Economics and Statistics 86.3, pp. 723-734.

Kadochnikov, Pavel, Sergey Sinel'nikov-Murylev, and Ilya Trunin (2002). "The System of Federal Aid to Russian Federation Subjects and Fiscal Behavior of Regional Authorities, 1994-2000". In: Voprosy Ekonomiki 8.

Khristenko, Viktor (2002). "Fiscal Federalism Development in Russia: Results of the 1990s and Tasks for the Future". In: Voprosy Ekonomiki 2.

Klimanov, Vladimir and Aleksei Lavrov (2004). "Intergovernmental Fiscal Relations in Russia in the Present Time". In: Voprosy Ekonomiki 11.

Kolomak, Evgenia (2014). "Development of Russian Urban System: Trends and Determinants". In: Voprosy Ekonomiki 10, pp. 82-96.

Krugman, Paul (1991). Geography and Trade. MIT Press.

Lavrov, Aleksei, John Litwack, and Douglas Sutherland (2001). "The Reform of Interbudgetary Relations in Russia: Federalism and Market Creation". In: Voprosy Ekonomiki 4, pp. 32-51.

Leksin, Vladimir (2006). "Regional Capitals in Russian Economic and Social Life". In: Voprosy Ekonomiki 7, pp. 84-93.

Leuthold, Jane H (1991). "Tax Shares in Developing Economies: A Panel Study". In: Journal of Development Economics 35.1, pp. 173-185.

Maddala, Gangadharrao S and Shaowen Wu (1999). "A Comparative Study of Unit Root Tests with Panel Data and a New Simple Test". In: Oxford Bulletin of Economics and Statistics 61.S1, pp. 631-652.

Mau, Vladimir and Konstantin Yanovskiy (2001). "Political and Legal Factors of Economic Growth in the Russian Regions". In: Voprosy Ekonomiki 11.

Mundell, Robert (1961). "A Theory of Optimal Currency Areas". In: American Economic Review 51.4 , pp. $657-665$.

Nazarov, Vladimir (2006). "Perspectives of Reforming the System of Interbudget Relations in Russia". In: Voprosy Ekonomiki 9, pp. 112-127.

OECD (2016). "Fiscal Federalism 2016: Making Decentralization Work". In: Organisation for Economic Cooperation and Development (OECD) Publishing, Paris. 
Pedroni, Peter and James Yudong Yao (2006). "Regional Income Divergence in China". In: Journal of Asian Economics 17.2, pp. 294-315.

Pelyasov, Alexander (2003). "Political and Economic Factors of Russian Regions Development". In: Voprosy Ekonomiki 5, pp. 67-82.

Riazantsev, Sergey (2005). "Internal Migration of the Russian Population: Trends and Social and Economic Consequences". In: Voprosy Ekonomiki 7, pp. 37-49.

Sen Gupta, Abhijit (2007). "Determinants of Tax Revenue Efforts in Developing Countries". In: International Monetary Fund Working Paper 07/184.

Shvetsov, Yuri (2005). "Evolution of Russian Fiscal Federalism". In: Voprosy Ekonomiki 8, pp. 7683.

Siluanov, Anton and Vladimir Nazarov (2009). "Coordination Between Federal and Regional Governments in Conducting Anti-Recession Policy: International Practice". In: Voprosy Ekonomiki 9, pp. $110-118$.

Tabakh, Anton and Daria Andreeva (2015). "Debt Strategies of Russian Regions". In: Voprosy Ekonomiki 10, pp. 78-93.

Yakobson, Lev (2006). "Budget Reform: Federalism or Management Aimed at Results?" In: Voprosy Ekonomiki 8, pp. 31-45.

Yushkov, Andrey (2016). "Fiscal Descentralization and Regional Economic Growth: Theory, Empirical Studies and Russian Experience". In: Voprosy Ekonomiki 2, pp. 94-110.

Yushkov, Andrey, Nina Oding, and Lev Savulkin (2017). "Trajectories of Donor Regions in Russia". In: Voprosy Ekonomiki 9, pp. 63-82.

Zubarevich, Natalia (2009). "Regional Development and Regional Policy in Russia during Ten Years of Economic Growth". In: New Economic Association Journal 1-2, pp. 61-174.

- (2014). "Center and Regions Interbudgetary Relations: Economic and Institutional Aspects". In: New Economic Association Journal 3(23), pp. 158-161. 


\section{Appendix A. Further Details about Fiscal Federalism in Russia}

This appendix summarizes revenue sources (including sharing arrangements), and spending responsibilities by different government levels. Concretely, Table A.1 catalogues federal taxes, special tax regimes, regional taxes, local taxes, and federal non-tax revenues, including their tax sharing between different levels of government, as specified in the Russian Legal framework. In turn, Table A.2, describes federal, regional/local, and joint federal-regional spending responsibilities, and specifies devolved federal spending responsibilities to regions (clarifying which are financed by subventions and which not).

\section{A.1 Limits Imposed by the Federal Government on Regional Budgets}

The Budget and Tax Codes establish several fiscal restrictions for sub-federal governments. Monitoring, reporting, and transparency standards and requirements established by the federal government are high. Sanctions for rules violations might be imposed and include, among other, adjustments in the size of transfers (excluding subventions).

Budget balance requirements: the deficit or regions cannot exceed 15 percent of their own revenues (excluding grants). Rules are stricter if federal grants exceed 40 percent of the consolidated region budget revenues (excluding subventions).

Tax limits: Sub-federal governments can set tax rates and reliefs for regional and local taxes. For the CIT, regions can set rates for the regional part of the tax within the limits set by the Tax Code but not reliefs. Excise taxes on gasoline and alcohol are shared annually between regions and federal government. The Tax Code does not allow for regions to legislate on PIT, fees and charges, rates and reliefs, which constitute the remaining 40 percent of their revenues.

Expenditure limits: Regions with a share of federal grants exceeding 10 percent of consolidated region budget revenues (excluding subventions) cannot assume and execute expenditures assigned to regional governments by Constitution and federal laws, and cannot exceed federal norms for budgetary sector wages and regional government activity financing. Similar restrictions exist for municipalities getting equalization grants from regions.

Borrowing constraints: Domestic borrowing is not directly restricted; new foreign borrowing (for deficit financing or refinancing) is allowed only for regions that do not receive federal equalization transfers, do not have debt arrears, and have proper credit ratings from at least two international agencies. Regions receiving federal equalization transfers can borrow externally to refinance existing external debt if no debt arrears and credit rating requirements are satisfied. Total yearly borrowing of regions and municipalities is bound up by deficit financing and debt amortization.

Debt levels and service: Debt is not allowed to exceed own annual revenues (excluding grants). Rules are stricter if federal grants share exceed 40 percent of consolidated region budget revenues (excluding subventions). Debt service (interest payments) should not exceed 15 percent of total expenditures (excluding subventions). Escape clauses introduce flexibility for regional budget implementation (budget credit financing, privatization, use of regional precautionary saving funds). Debt ceilings are currently allowed to be exceeded for an amount equal to federal budget credits. 
Table A.1: Tax and Non-Tax Revenue Sharing Agreement

\begin{tabular}{|c|c|c|c|c|}
\hline \multirow{2}{*}{ Federal taxes } & \multirow{2}{*}{ Rates (percent) } & \multicolumn{3}{|c|}{ Share accruing to (in percent of total) } \\
\hline & & Federal & Regional & Municipa \\
\hline VAT & 18 (concessional rate 10 percent) & 100 & & \\
\hline PIT & 13 & 0 & 85 & 15 \\
\hline CIT 1/ & 20 & 10 & 90 & \\
\hline MET (Oil and Gas) & Formula-based depending on oil price & 100 & & \\
\hline MET (Other subsoil resources, including diamonds) & Ad valorem and specific & 40 & 60 & \\
\hline MET (Commonly occurring subsoil resources) & Ad valorem and specific & & 100 & \\
\hline MET (Diamonds) & 8 & & 100 & \\
\hline Water tax & Specific & 100 & & \\
\hline Excise tax on ethanol from edible raw material $2 /$ & Specific & 50 & 50 & \\
\hline Excise tax on ethanol from all material excluding edible $2 /$ & Specific & 100 & & \\
\hline Excise tax on alcohol-containing products $2 /$ & Specific & 50 & 50 & \\
\hline Excise tax on spirits $2 /$ & Specific & 50 & 50 & \\
\hline Excise tax on wine, beer, other $2 / 3 /$ & Specific & & 100 & \\
\hline Excise tax on tobacco $2 /$ & Specific & 100 & & \\
\hline Excise tax on cars and motocycles $2 /$ & Specific & 100 & & \\
\hline Excise on gasoline and motor oil $2 / 4 / 5 /$ & Specific & 12 & 88 & \\
\hline Excise tax on imported excisable goods $2 /$ & Ad valorem and specific & 100 & & \\
\hline Fee (royalty) for exploitation of water biological resources & Specific & 20 & 80 & \\
\hline Fee (royalty) for exploitation of animal resources & Specific & & 100 & \\
\hline Stamp duty $6 /$ & Specific & 100 & 100 & 100 \\
\hline Stamp duty via public multi-service centers & & 50 & 50 & \\
\hline
\end{tabular}

\begin{tabular}{lcc}
\hline \multicolumn{1}{c}{ Special Tax Regimes } & Rates (percent) & \multicolumn{2}{c}{ Share accruing to (in percent of total) } & Federal & Regional & Municipal \\
\hline Single agricultural tax & 6 & 100 \\
Single imputed income tax & $15(7.5-15)$ & 100 \\
Patent & 6 & 100 \\
Simplified taxation regime & 6 or 15 & 100 \\
Taxes under Product sharing agreements & & 25
\end{tabular}

\begin{tabular}{|c|c|c|c|c|}
\hline \multirow{2}{*}{ Federal Non-Tax Revenues } & \multirow{2}{*}{ Rates (percent) } & \multicolumn{3}{|c|}{ Share accruing to (in percent of total) } \\
\hline & & Federal & Regional & Municipal \\
\hline Property income and earnings from paid services & & 100 & 100 & 100 \\
\hline License fees & & 100 & & \\
\hline Customs duties and fees & & 100 & & \\
\hline Forests & & 100 & 100 & 100 \\
\hline Water facilities & & 100 & 100 & 100 \\
\hline Environmental Fee 7/ & & 5 & 40 & 55 \\
\hline Consular fees & & 100 & & \\
\hline Disposal fee & & 100 & & \\
\hline Subsoil royalty & Formula-based & 40 & 60 & \\
\hline Proceeds from sale/lease of federal land ceded to region & & & 50 & 50 \\
\hline Fees for record extracts & & 100 & 100 & 100 \\
\hline Fees for record extracts via public multi-service center & & 50 & 50 & \\
\hline
\end{tabular}

Fines and penalties 8/

\begin{tabular}{|c|c|c|c|c|}
\hline \multirow{2}{*}{ Regional Taxes } & \multirow{2}{*}{ Rates (percent) } & \multicolumn{3}{|c|}{ Share accruing to (in percent of total) } \\
\hline & & Federal & Regional & Municipal \\
\hline Corporate property tax & Capped at 2.2 & & 100 & \\
\hline Gambling tax & Specific & & 100 & \\
\hline Transport tax & Specific & & 100 & \\
\hline \multirow{2}{*}{ LocalTaxes } & \multirow{2}{*}{ Rates (percent) } & \multicolumn{3}{|c|}{ Share accruing to (in percent of total) } \\
\hline & & Federal & Regional & Municipal \\
\hline Land tax & Capped at 0.3 and 1.5 for diff.types of land & & & 100 \\
\hline Personal property tax & $0.1-2$ & & & 100 \\
\hline Retail sales fee (so far implemented only in Moscow) & Specific, but no more than patent-based & & & 100 \\
\hline
\end{tabular}

Source: Russian Tax Code (articles 13-15; 18; 143-418); and, Russian Budget Code (articles 46, 56-64).

Notes:

1/ The CIT is the only tax whose rate is split between the federal and the regional levels in the Tax Code (sharing of other taxes is established in the Budget

Code). Regions are authorized to adjust their portion of the CIT rate down, but no more than to 13.5 percent (12.5 percent in 2017-20). For 2017-20, the

federal government will receive an additional $1 \mathrm{pp}$ to be redistributed via equalization grants. This may result in a financing gap for some regions.

2/ The tax code sets the corresponding rates in Rubles for 2017-19.

3/ As established in the Budget Code (article 56, 2.2). For 2017, the distribution of these revenues shall be governed by the Federal Budget Law.

4/ These shares are suspended for 2017-2020 by law 409-FZ of 30 November 2016.

5/ Gasoline and diesel oil excise revenues shall be attributed to the federal budget according to the following shares: 38.3 percent in 2017,

42.6 percent in 2018 , and 39.8 percent in 2019 . The remaining portion will go to the regional budgets.

6/ Whenever share of federal, regional and local government is reported simultaneously as 100 it means that each of them receives the full share

of the tax revenue in application to its own jurisdiction.

7/ 95 percent in Moscow, Saint Petersburg. The federal 5 percent is planned to be given over to municipalities in 2018

8/ Numerous fines and penalties are distributed in various shares (including 100 percent) among different government levels. 
Table A.2: Spending Responsibilities and Jurisdiction by Level of Government

\begin{tabular}{|c|c|c|c|}
\hline Area & Federal & Joint Federal Regional & Regional / Local \\
\hline General & $\begin{array}{l}\text { Exclusive Federal Jurisdiction: Authority on federal } \\
\text { property, regulation of social and economic } \\
\text { development, federal energy systems, national } \\
\text { defense and security, international relations, law } \\
\text { enforcement; meteorology and statistics. }\end{array}$ & $\begin{array}{l}\text { Areas of joint federal-regional jurisdiction: Public } \\
\text { safety and law enforcement; administrative, labor, } \\
\text { family, housing, land, subsoil, forest, water } \\
\text { relations; environmental protection; emergencies } \\
\text { and natural disasters; education, science, culture, } \\
\text { sports; public health, social security. } \\
\text { Responsibilities are usually divided based on } \\
\text { jurisdictional attribution or relevance (e.g. regional } \\
\text { roads or federal water facilities), but sometimes } \\
\text { are shared between the two levels of government. }\end{array}$ & $\begin{array}{l}\text { Exclusive Regional Jurisdiction: all other } \\
\text { government responsibilities beyond those under } \\
\text { the federal jurisdiction and joint federal-regional } \\
\text { jurisdiction - as stipulated in regional constitutions } \\
\text { and legislation. Local Governments' jurisdiction: } \\
\text { Urban, rural settlements; electricity, heating, } \\
\text { water, gas, fuel supply; roads; municipal housing; } \\
\text { public transport; emergencies, fire safety; public } \\
\text { amenities, eateries, retail trade; culture (local } \\
\text { cultural heritage, folk art and crafts); physical } \\
\text { culture, sports, public entertainment, recreation; } \\
\text { archives; cemeteries; local resorts; public safety, } \\
\text { rescue operations; waste management; support to } \\
\text { agriculture and SMEs; terrorism/ extremism } \\
\text { prevention; education (less vocational + } \\
\text { vacations); public health. }\end{array}$ \\
\hline
\end{tabular}

Delegated federal

Responsibilities

supported by federal

subventions

National Census and Agricultural Census; Prevention of homelessness; Housing for disabled, veterans, retired servicemen, etc.; Subsidization of housing and utility payments for veterans, disabled, radiation-exposed, etc.; payouts to radiation-exposed; unemployment benefits; maternity and childcare benefits; monthly compensation payouts to various categories, e.g. exposed to radiation, blood donors, etc.; water and forest relations: management (partial) of federal water facilities and forests; animal world, hunting, fishing (partial); protection and oversight of cultural heritage; education: oversight, licencing, accreditation (all partial); public health: licensing; procurement of drugs, mandatory medical insurance.

\author{
Delegated federal \\ Responsibilities \\ unsupported by federal
}

subventions

Audit of construction plans and engineering surveys; environmental audit; land relations: provision of plots of land for construction, demolition of real estate, easement; R\&D management.

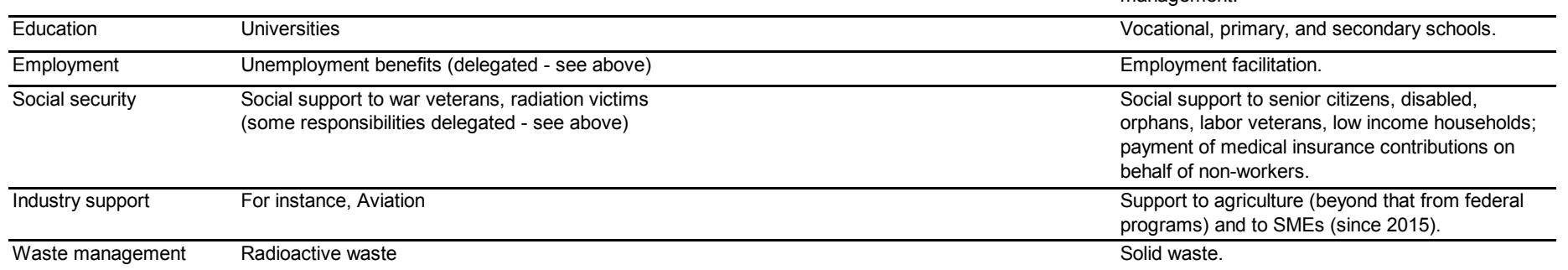

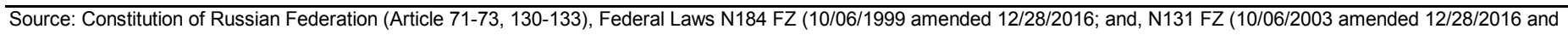
updated 02/17/2017); list of regional responsibilities (Ministry' of Justice website, http://minjust.ru/ru/razvitie-federativnyh-otnosheniy-i-mestnogo-samoupravleniya/razgranicheniepolnomochiy-mezhdu).

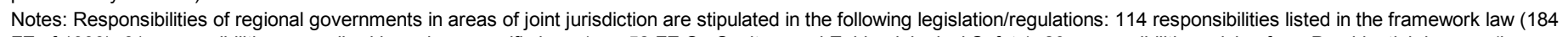
FZ of 1999); 61 responsibilities prescribed in various specific laws (e.g. 52 FZ On Sanitary and Epidemiological Safety); 20 responsibilities arising from Presidential decrees (in particular decrees of May 2012), e.g. social suppor to medical workers, their professional development, employment of disabled, housing, increase in salaries for teachers and

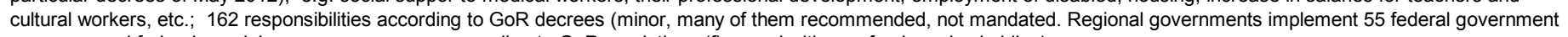
programs and federal special-purpose programs - according to GoR resolutions (financed with own funds and subsidies).

21

\title{
CInternational Monetary Fund. Not for Redistribution
}




\section{Appendix B. Data}

Table B.1 provides the definition for the variables used in the analysis.

Table B.1: Variable Definitions

\begin{tabular}{ll}
\hline \multicolumn{1}{c}{ Variable } & \\
\hline Change in the share of public sector in GRP & Change in the share of public sector in GRP in 2004-15 (percent) * \\
Common border & Dummy identifying regions sharing a common border * \\
Federal transfers as a share of GRP & Average federal transfers-to-GRP ratio in 2005-15 (percent) * \\
Footprint of state & Ln of number of per capita budgetary and non-budgetary state institutions * \\
Foreign trade & Average Exports plus Imports over GRP for 2009-15 (percent) * \\
Initial per capita real GRP & Ln of real per capita GRP in 2003 * \\
Per capita real federal transfer growth correlation & Bilateral regional corr. of real per capita federal transfer growth for 2005-15 (excluding \\
& tansfers to territorial EBFs) \\
Per capita real grant growth correlation & Bilateral regional correlation of real per capita federal grants growth for 2005-15 \\
Per capita real GRP growth & Annual average growth rate (Ln difference) of real per capita GRP in 2004-15 * \\
Per capita real GRP growth correlation & Bilateral regional corr. of real per capita GDP growth for 2005-15 \\
Per capita real subsidy growth correlation & Bilateral regional corr. of real per capita federal subsidies growth for 2005-15 \\
Per capita real subvention growth correlation & Bilateral regional corr. of real per capita federal subventions growth for 2005-15 \\
Population & Ln of population (millions) in 2005 * \\
Population density & Ln of population density (people per square kilometer) in 2005 * \\
Revenue-to-expenditure ratio & Annual average change of the revenue-to-expenditure ratio in 2005-15 (percent) * \\
Share of mining in GRP & Average share of mining in GRP in 2004-15 (percent) * \\
Share of public sector in GRP & Average share of public sector in GRP in 2004-15 (percent) * \\
Urbanization rates & Average urbanization rates for 2005-15 (percent) *
\end{tabular}

